\title{
Do Macroeconomic Variables Influence Domestic Stock Market Price Behaviour in Emerging Markets? A Johansen Cointegration Approach to the Botswana Stock Market
}

\author{
${ }^{1}$ Onneetse L. Sikalao-Lekobane, ${ }^{2}$ Khaufelo Raymond Lekobane* \\ ${ }^{1}$ Bank of Botswana, Botswana \\ ${ }^{2}$ Botswana Institute for Development Policy Analysis (BIDPA), Botswana \\ *rlekobane@bidpa.bw
}

\begin{abstract}
The ability of the stock market to reflect real economic activities through fundamental macroeconomic variables in emerging markets remains paramount considering the role of stock markets in the financial system. This paper explores the long-term equilibrium relationship between the Botswana stock market price and selected domestic and global macroeconomic variables using quarterly data for the period 1998 to 2012. The selected macroeconomic variables included Gross Domestic Product (GDP), long and short-term interest rates, money supply, foreign reserves, inflation, diamond price index, exchange rate, US share price index and 10 Year US government bond yield. The paper employs VECM framework following Johansen's cointegration technique. The analysis revealed that macroeconomic variables and the stock market price are cointegrated, hence, a long-run equilibrium relationship existed between them. The results showed that in the long run, real GDP, short-term interest rates, inflation and diamond index are positively related with stock market price. However, long-term real interest rate, money supply, foreign reserves, exchange rate, US share price index and US government bond yield are negatively related with stock market price in the long run.
\end{abstract}

Keywords: Botswana, Stock Market Price, Vector Error Correction Model (VECM), Johansen's Cointegration, Macroeconomic Variables

\section{Introduction}

The modern financial theory has shed some light in explaining the sensitivity of stock price movements relative to the changes in fundamental macro-economic forces. The underlying puzzle that interest researchers is whether information on changes in macroeconomic factors is instantly reflected in the stock price by market analyst and whether the same fundamental results in developed markets will be similar to that of developing markets, thus posing question of market efficiency. The theoretical basis to investigate this relationship is well documented in economic literature such as in Baumol (1965) and Bosworth (1975). An extensive literature exists and provides various reasons explaining the linking behaviour of stock return to key macroeconomic variables across different markets and time horizons. Similarly, financial economic theory with various models exists thus proving a strong base to study this relationship. Friedman (1988) highlights that there are channels through which stock price may directly influence money demands in the economy citing the 'wealth and substitution effects'. Sharpe's (1964) Capital Assert Pricing Model (CAPM) became one of the pioneers of modern financial theory although the theory was described as unrealistic by most economists due to its focus on one single index model which claims that stock price depends only on market factors. An alternative and testing of asset pricing models called Arbitrage Pricing Theory (APT) was later developed by Ross's (1976) stating that asset return can be explained by multiple risk factors. A number of APT theory based empirical studies by the likes of Fama (1981,1990), Fama and French (1989), Black et al. (1972) collectively conceded that there exists a significant relationship between stock market prices and macroeconomic variables such as inflation, production index, yield curve, interest rates and risk premium. Another alternative approach was developed by Chen et al. (1986) which use the Present Value Model (PVM) or discounted cash flow approach to investigate the impact of systematic risk factors on returns through all macroeconomic factors influencing future expected cash flows and future discount rates. Although both theories do not specify these factor variables, Chen et al (1986) empirically argue that stock should be sensitive to any factor that influences future cash flows or their discount rate. The two modern theories-CAPM and APT are partly based on the Efficient Market Hypothesis (EMH) by Fama (1965), which states that at any given time, security prices fully reflect all available information hence investors should not be able to consistently earn abnormal returns. Therefore, in an information efficient market, past information should not be useful in predicting future stock prices. On a different note, if indeed stock prices are a 
reflection of the underlying fundamentals given all the available information, then it would be rational to say that they are a perfect indicator of future economic activities and their causal relations with other economic variables could be used to guide policy makers and investors.

This paper therefore, intends to explore the long-run relationship between key macroeconomic variables and stock market price in emerging markets considering the case of Botswana. The study captures the impact of both domestic and global economic factors on real stock market price. The underlying question seeks to investigate whether Botswana stock market return is driven by macroeconomic fundamentals. As global markets are becoming increasingly integrated, a challenged posed to investors is how the global market forces impact stock market price especially in emerging markets which are believed to be less integrated with the developed markets. The inclusion of global variables follows papers by Fifield et al. (2002), Srinivasan (2011), Alshogeathri (2011) and Hsing (2011) who examined the influence of global macroeconomic variables on emerging stock market in India, South Africa and Saudi respectively. The question of whether the selected variables are significant explanatory factors of stock price is an empirical principle. Logically, if the variables are significant and consistently reflective of the stock movement, cointegration is expected to exist. Absence of association therefore, may signal that the stock market is not responsive to changes in real economic activities and pose questions of efficiency. Based on logical economic sense that a certain co-movement and interaction exist between economic factors and stock prices in emerging markets despite limitations in their financial structuring and market efficiencies, it is empirically relevant to investigate the dynamics of what moves stock prices. With limited research in Botswana regarding this area, this study seeks to provide a bridging gap for future studies. The paper is organized as follows. Section 1 provides the introduction whilst section 2 covers the literature review. In section 3 we cover the data and methodology used. Section 5 presents the estimation results and discussion whilst section 6 concludes the paper.

\section{Literature Review}

Extensive literature and research has been undertaken to determine relationship of stock market against fundamental economic variables especially in developed market. Although there has been steaming interest to investigate the same effect for emerging markets, empirical results in certain markets especially smaller economies such as Botswana remains scarce. The basis of the relationship between changes in stock prices and macro-economic variables was first developed by Fama and Schwert (1977). Earlier papers by Chen et al. (1986) identified a number of important macroeconomic variables which are likely to influence stock price behaviour through the basic valuation model. This list was later emulated and extended by various researchers who recorded varying responses in different regions. The dynamics of research was later extended by Engle and Granger (1987) and Granger (1986) who developed the cointegration technique to measures validity of long-term equilibrium between variables. This same technique has been utilized by numerous researchers including Mukherjee \& Naka (1995), Nasseh \& Strauss (2000), Maysami \& Koh (2000), Chaudhuri \& Smiles (2004), Humpe \& Macmillan (2009), Hussin, et al. (2012). Mukherjee \& Naka (1995) employed VECM to investigate the Japanese stock price and found cointegrating relationship between macroeconomic variables namely inflation, money supply, real economic activity, long-term government bond rate, industrial production, call money rate and exchange rate. They found positive association for money supply, exchange rate and industrial production whilst for interest rate and inflation was mixed. Jefferis and Okeahalam (2000) using cointegration and error correction approaches investigate the impact of both domestic and foreign economic factors on South Africa, Zimbabwe and Botswana, and found the Botswana stock market to positively relate with GDP and exchange rate and negatively influenced by short-term interest rates. Rahman et al. (2009) applied VECM and cointegration technique on Malaysian stock market and found positive association on foreign exchange reserves; interest rates and industrial production index whereas money supply and exchange rate were inversely related to stock price in the long run.

The documented relationship between stock return and inflation shows mixed results across regions. This relationship dates back to Fisher (1930) hypothesis, and in its most familiar versions, stating that "the expected nominal rate of return on stock is equal to expected inflation plus the real rate of return". Fisher hypothesis clearly depicts a positive relationship between stock returns and inflation, implying that stocks offer a hedge against inflation. Fama \& Schwert (1977), Chen et al. (1986), Geske \& Roll (1983), DeFina (1991), Ralph \& Eriki (2001), Omrana, (2003), Adam \& Frimpong (2010) and Hsing (2011) also supported the hedge hypothesis. Kumari (2011) asserts that a hedge is obtained when investor is fully compensated for price rise through an increase in nominal stock return thereby leaving 
stock returns unaffected. Testing Fishers hypothesis in emerging markets has however yielded some contradicting results. Spyrou (2001) and Floros (2004) used the Johansen cointegration test and found no significant long-run relationship between inflation and stock returns in Greece. Davis and Kutan (2003) investigated the Fisher hypothesis in 13 developed and developing countries and found evidence that Fisher effect is not evidenced in international stock returns. Spyrou (2004) also found little evidence supporting the fisher effect on a mix of nine emerging countries. Al-Khazali and Pyun (2004) testing cointegration in the pacific region found negative relationship in the short-run and positive relationship in the long-run. Geske and Roll (1983) and Mukherjee and Naka (1995) recorded negative relationship. Ibrahim and Yussof (2001) found a positive relationship between Malaysian stock market and inflation in the long run.

The relationship of interest rates on stock return has also been investigated generally indicating a negative relationship. Ratanapakorn and Shama (2007) found a negative relationship between long-term interest rates in the long run and positive short-term interest rates. However Hsing (2011) and Rahman et al. (2009) found a positive relationship whilst Humpe and Macmillan (2009) found a negative relationship. Galebotswe and Thalefang (2012) and Nemaorani (2012) investigated the effects of monetary policy shocks on Botswana's stock returns and found a positive association for short-term interest rates. Conversely, Jefferis and Okeahalam (2000) reported a negative relationship in Botswana. Existing literature regarding relationship between exchange rates and stock price is inconclusive especially in emerging markets. Aggarwal (1981), Mukherjee and Naka (1995), Maysami and Koh (2000) and Ibrahim (2003) found a positive relationship whilst Soenen and Hennigar (1988), Rahman et al. (2009) and Ibrahim and Aziz (2003) found a negative relationship. Granger et al (2000) investigated the relationship for nine Asian countries during the Asian financial crisis and found no cointegration. Ibrahim (2000) also tested the Malaysian stock market and found no cointegration. Hsing (2011) found a positive relationship in South Africa similar to Jefferis and Okeahalam (2000) in Botswana.

Conflicting results on the relationship of money supply and stock price have been noted. Errunza and Hogan (1998), Dhakal et al. (1993), Mukherjee and Naka (1995), Ratanapakon and Sharma (2007) and Hsing (2011) found a positive relationship between money supply and stock price. Fama (1981), Ibrahim and Yassuf (2001), Ibrahim and Aziz (2003), Humpe and Macmillan (2007) and Rahman et al (2009) found a negative relationship. There is a common consensus among many researchers that the movement of stock price is vital in predicting future economic growth and productivity and that GDP is a leading indicator of stock movement (Levine and Zervos, 1998; Glen, 2002; Ritter, 2005). Fama (1981), Mukherjee and Naka (1995), Maysami and Koh (2000), Ibrahim (2003), Jefferis and Okeahalam (2000) and Hsing (2011) indicate a strong positive relationship between GDP and stock prices. Gjerde and Saettem (1999) studies four developed markets and found a positive association even though they noted a delayed response of stock market price to changes in GDP. The relationship between foreign reserves and stock return is expected to be positive. Mookerjee and Yu (1997) using cointegration approach reveal that foreign reserves together with narrow and broad money supply exhibited a long-run relationship in the Singapore stock market thus excluding exchange rates. Muhammad et al (2009) found significant influence of foreign exchange reserve and foreign exchange rate on Karachi stock price. Rahman et al (2009) found a positive association between stock market price and foreign exchange reserves in the Malaysian stock market.

The impact of diamond price on stock price may vary depending on whether the economy under study is a diamond importer or exporter. Levenstein and Suslow (2006), Shevelyova (2006) and Spar (2006) are of the view that diamonds have for long been completely ignored in top-tier finance and research despite their similar traits to gold commodity. In a rare study concerning diamond prices, Renneboog and Spaenjers (2012) studies the market for investment grade-gems (white and coloured diamonds) using hedonic regression approach. They state that "diamonds returns co-vary with stock markets return" confirming previous evidence by Ait-Sahalia et al. (2004) on the importance of wealth effect on demand for luxury goods consumption. They reported that diamonds outperformed stock market even though their return faired below Gold price since 1999. Auer and Schuhmacher (2013) investigated the performance and role of diamonds and traditional asset classes as a potential diversifier in a world market portfolio. Their evidence shows that low time varying correlation to traditional asset classes indicate some potential diversification benefits. The relationship between global market factors and stock market has been scarcely explored. Fifield et al. (2002) concluded that global factors are significant in explaining the behaviour of emerging stock markets. Alshogeathri (2011) and Srinivasan (2011) also found a positive long-run relationship between US Stock market and the Saudi and India stock price 
respectively. Hsing (2011) found a positive influence of the US stock price and a negative relationship between the US government bond yield.

\section{Methodology}

Data: The study used quarterly data for a 14 year period from 1998(Q1) to 2012(Q4). The secondary data for key macroeconomic variables were obtained from various sources mainly the Bank of Botswana (BoB) and International Financial Statistics (IFS) database and annual reports, except two international macroeconomic variables (US Share Price Index and 10 year Government bond yield) which were derived from the IMF International Financial Statistics (IFS) and DataStream terminal databases, respectively. All the variables except interest rates (short-term and long-term) are expressed in natural logarithms. Table 1 provides the description of the variables used in the study.

\begin{tabular}{lll}
\multicolumn{2}{l}{ Table 1: Description of variables } \\
\hline Variable & Concept & Description \\
\hline DCI & Stock Prices (domestic) & Domestic Company Index \\
GDP & Output & Real Gross Domestic Product \\
RIR & Long Term Interest Rates & Real Interest Rate (Prime) \\
BoBCR & Short Term Interest Rates & 3-months Bank of Botswana Certificate (BoBC) \\
M2 & Monetary Base (quasi money) & Money Supply \\
FR & Foreign Reserves & Foreign Reserves \\
CPI & Measure of Inflation & Consumer Price Index \\
DI & World Diamond Prices & Diamonds Index \\
ER & Exchange Rate & Exchange Rate (Nominal) \\
USSPI & World Stock Market Index & US Share Price Index \\
USGBY & World Interest Rates & 10 Year US Government Bond Yield \\
\hline
\end{tabular}

The model: This paper employed VECM framework following Johansen $(1991 ; 1995)$. This framework is used to avoid potential misspecification biases that might result from the use of a conventional VAR modelling technique (Agrawalla and Tuteja, 2008). Similar approach has been followed by other researchers (Mitra, 2013; Hussin et al., 2012; Humpe and Macmillian, 2009; Sohail and Hussain, 2009; Mukherjee and Naka, 1995). Following Johansen (1995), the multivariate VECM can be rewritten as

$$
\Delta Y_{t}=v+\Pi Y_{t-1}+\sum_{t=1}^{p-1} \Gamma_{i} \Delta Y_{t-1}+\varepsilon_{t}
$$

where $\Delta$ is the first difference operator, $Y_{t}$ is a $(K \times 1)$ vector of I(1) variables, $\Pi$ is $(K \times r)$ parameter matrix with $\operatorname{rank} r<K$, representing the adjustment to disequilibrium following an exogenous shock, where $r$ and $k$ denote the rank of $\Pi$ and the number of variables constituting the long run relationship, respectively. If $\Pi$ has reduced rank, $r<K$, then there exist two $(K \times r)$ matrices of $\alpha$ and $\beta$, each with rank $r$, such that $\Pi=\alpha \beta^{\prime}$ and $\beta^{\prime} Y_{t}$ is stationary. The elements of the $\alpha$ matrix represent the adjustment or loading coefficients, and indicate the speed of adjustment of the endogenous variables in response to disequilibrating shocks. $\Gamma_{1}, \Gamma_{2}, \ldots, \Gamma_{p-1}$ are $(K \times K)$ matrices of parameters, capturing the short-run dynamic adjustments, and $\varepsilon_{t}$ is a $(K x 1)$ vector of normally distributed errors that is serially uncorrelated but has contemporaneous variance matrix $\Omega$.

\section{Results and Discussion}

Unit root test: The first step involved the examination of the stationary properties of the data using the Augmented Dickey-Fuller $(A D F)$ and the Phillips-Perron $(P P)$ tests at both levels and first-differences (Dickey and Fuller, 1979; 1981; Phillips and Perron, 1988). The results show that the variables were stationary at levels and integrated at first order I(1) (Table 2).

Cointegration Analysis: In modelling the long-run relationship between macroeconomic variables and the dependent variables, cointegration analysis is the ideal tool (Humpe and Macmillian, 2009). This study therefore adopted Johansen (1995) cointegration technique to investigate long-run relationship of the stock market and selected macroeconomic variables. After establishing that the variables were firstdifference stationary I(1), the optimum lag-length for VECM is determined using the Akaike Information Criterion (AIC), Swartz-Bayes Information Criterion (SBIC), Final Prediction Error (FPE), Hanna and Quinn (HQC), and Likelihood Ratio (LR). As it often happens that the tests show different lag orders, the 
AIC test showed a lag of four compared to other tests which indicate a lag of one (Table 3). These lags refer to the number of lags in the underlying VAR "levels", which, when reparametized into a VECM include one fewer lags. Therefore our VECM model will have three lags as shown by the AIC test.

Table 2: Unit root test

\begin{tabular}{|c|c|c|c|c|c|c|}
\hline \multirow[b]{2}{*}{ Variable } & \multicolumn{3}{|c|}{ Augmented Dickey Fuller } & \multicolumn{2}{|c|}{ Phillips-Perron } & \multirow[b]{2}{*}{$\begin{array}{l}\text { Order of } \\
\text { Integration }\end{array}$} \\
\hline & Levels & $\begin{array}{l}\text { First } \\
\text { Difference }\end{array}$ & $\begin{array}{l}\text { Order of } \\
\text { Integration }\end{array}$ & Levels & $\begin{array}{l}\text { First } \\
\text { Difference }\end{array}$ & \\
\hline DCI & 0.9845 & $0.000^{* * *}$ & $\mathrm{I}(1)$ & 0.9955 & $0.000^{* * *}$ & $\mathrm{I}(1)$ \\
\hline GDP & 0.9999 & $0.0129 * *$ & $\mathrm{I}(1)$ & 1.0000 & $0.000^{* * *}$ & $\mathrm{I}(1)$ \\
\hline RIR & 0.2909 & $0.000^{* * *}$ & I(1) & 0.2732 & $0.000^{* * *}$ & I(1) \\
\hline BoBCR & 0.1135 & $0.000^{* * *}$ & $\mathrm{I}(1)$ & 0.1981 & $0.000^{* * *}$ & $\mathrm{I}(1)$ \\
\hline M2 & 1.0000 & $0.000^{* * *}$ & $\mathrm{I}(1)$ & 1.0000 & $0.000^{* * *}$ & $\mathrm{I}(1)$ \\
\hline FR & 0.9267 & $0.0200 * *$ & $\mathrm{I}(1)$ & 0.9493 & $0.000^{* * *}$ & I(1) \\
\hline CPI & 1.0000 & $0.000^{* * *}$ & $\mathrm{I}(1)$ & 1.0000 & $0.0234^{* *}$ & $\mathrm{I}(1)$ \\
\hline DI & 0.6716 & $0.001^{* * *}$ & $\mathrm{I}(1)$ & 0.6231 & $0.000^{* * *}$ & $\mathrm{I}(1)$ \\
\hline ER & 0.8706 & $0.000^{* * *}$ & $\mathrm{I}(1)$ & 0.8574 & $0.000^{* * *}$ & $\mathrm{I}(1)$ \\
\hline USGBY & 0.1017 & $0.000^{* * *}$ & $\mathrm{I}(1)$ & 0.1171 & $0.000^{* * *}$ & $\mathrm{I}(1)$ \\
\hline USSPI & 0.7877 & $0.000^{* * *}$ & $\mathrm{I}(1)$ & 0.8962 & $0.000^{* * *}$ & $\mathrm{I}(1)$ \\
\hline
\end{tabular}

Table 3: Lag-order selection criteria

\begin{tabular}{lllllllll}
\hline Lag & LL & LR & df & P & FPE & AIC & HQIC & SBIC \\
\hline 0 & 63.2011 & & & & 0.009122 & -1.86433 & -1.71009 & -1.46649 \\
1 & 81.8564 & $37.311^{*}$ & 1 & 0.000 & 0.004863 & -2.49487 & $-2.32661^{*}$ & $-2.06087^{*}$ \\
2 & 82.3812 & 1.0496 & 1 & 0.306 & 0.004956 & -2.47790 & -2.29562 & -2.00773 \\
3 & 83.488 & 2.2135 & 1 & 0.137 & 0.004948 & -2.48171 & -2.28541 & -1.97538 \\
4 & 85.3551 & 3.7342 & 1 & 0.053 & $.004809^{*}$ & $-2.51268^{*}$ & -2.30235 & -1.97018 \\
\hline
\end{tabular}

After unit root tests and choosing the number of lags, the next step is to determine the number of cointegrating equations $(r)$ in a VECM, using the Johansen's trace statistics. The null hypothesis of the trace statistics is that there are no more than $r$ (where $r$ is the rank) cointegrating equations. Employing the Johansen's methodology, the paper restricted the number of cointegrating equations to be $r$ or less. This implies that the remaining $(K-r)$ eigenvalues are zero (Johansen, 1995). The distribution of the trace statistic is

$\lambda_{\text {trace }}=-T \sum_{i=r+1}^{k} \ln \left(1-\hat{\lambda}_{i}\right)$

Where $T$ is the number of observations and $\hat{\lambda}$ are the estimated eigenvalues. For any given value of $r$, large values of trace statistic are evidence against the null hypothesis that there are $r$ or less cointegration in the VECM. According to the results of the trace statistics, we may not reject the null hypothesis that the number of cointegrating vectors is less than or equal to two against the general alternative that it is greater than two at $5 \%$ significant level. We then conclude that the final number of cointegrating vectors to be included in the VECM is equal to nine, i.e. rank ( $\Pi)=9$ and that we have long-run equilibrium. However, since the study is only interested in the log-run relationship between stock market price and the explanatory variables we only report one equation.

Table 4: Johansen's test for cointegration

\begin{tabular}{llllll}
\hline Maximum Rank & parms & LL & Eigenvalue & Trace statistic & $\mathbf{5 \%}$ Critical value \\
\hline 0 & 374 & 1031.589 & & 1296.857 & 277.7 \\
1 & 395 & 1260.527 & 0.99972 & 838.981 & 233.1 \\
2 & 414 & 1365.171 & 0.97618 & 629.693 & 192.9 \\
3 & 431 & 1443.802 & 0.93969 & 472.432 & 156.0 \\
4 & 446 & 1513.503 & 0.91703 & 333.029 & 124.2 \\
5 & 459 & 1562.098 & 0.82369 & 235.839 & 94.2 \\
6 & 470 & 1600.104 & 0.74267 & 159.826 & 68.5 \\
7 & 479 & 1633.696 & 0.69872 & 92.643 & 47.2 \\
8 & 486 & 1656.058 & 0.55006 & 47.919 & 29.7 \\
9 & 491 & 1672.338 & 0.44090 & $15.3588^{*}$ & 15.4 \\
\hline
\end{tabular}


Empirical Results: Table 5 presents the Johansen normalized cointegration equation for the stock price (DCI). The results reveal that GDP is positively and significantly related to stock price. This positive relationship is regarded as a symbol of a healthy economic situation stirring a positive effect on firms' earnings, thus increasing stock price. Unlike most emerging markets, Botswana has always maintained sustainable economic growth, good credit ratings and low debt levels. Although during financial crisis the country experienced slight decline on GDP growth due to decline in the mining sector, the effect of the sub-prime and financial crisis was minimal in other sectors such as the financial sector. No bank failures were experienced due to the country's strong financial regulation. The results are consistent with other studies (Fama, 1981; Jefferis and Okeahalam, 2000; Chaudhiri and Smiles, 2004; Ratanapakorn and Sharma, 2007; Rahman et al., 2009; Yu Hsing, 2011). The stock price displayed a negative relationship with long term real interest rate (RIR) and a positive association with short-term interest rates (BoBCR). The results of the BoBCR collaborate with those of Galebotswe and Tlhalefang (2012) and Nemaorani (2012). They explained the anomaly in short term interest as attributed by over reliance of banks on BoBCs for investment and the dominance of the major commercial banks in the stock market thus offsetting the non-banks companies. The negative relationship with long term real interest rates on the other hand collaborates with Ratanapakorn and Shama (2007) and Humpe and Macmillan (2009). It also agrees with economic theory that rise in interest rates will increase the risk free nominal interest rate and discount rate thus reducing the stock price (Abdullah and Hayworth, 1993). In other words a rise in long-term interest rate depresses and slows down economic activity and corporate profits thus impacting on the stock price.

The findings suggest that money supply (M2) possess a significant but negative impact in the stock price. These results collaborate with other studies (Humpe and Macmillian, 2009; Ibrahim and Yassuf, 2001; Ibrahim and Aziz, 2003). Fama (1981) attributes the negative relationship to the direct positive relationship of money supply and inflation. Humpe and Macmillan (2009) indicate that money supply is likely to influence share price through transmission mechanism of monetary policy stating that, if changes in money supply is a result of increase in inflation or future inflation uncertainty, then the effect on stock price would be negative. Foreign reserves (FR) are negatively related with stock price which is inconsistent with economic theory. The country's foreign exchange reserve are US dollar based hence may exhibit the negative challenges faced by the base currency coupled with other general effects of decline in the major economic contributor (diamond exports) and other external forces such as the financial crisis. Inflation (CPI) is positively and significantly related with stock price. This corresponds with previous papers by Fama and Schwert (1977), Geske and Roll (1983), Chen et al. (1986), DeFina (1991), Ralph and Eriki (2001), Omrana (2003) and Hsing (2011). As significant de-trending was experienced during the selected period due to changes in monetary and fiscal policies, financial crisis and changes in exchange rate regimes, inflation remained relatively high during the period. The results however, confirm the Fishers' inflation hedge hypothesis.

As expected, diamond index (DI) is positively and significantly related with stock price. The results confirm previous evidence by Renneboog and Spaenjers (2012). As Botswana economy is heavily reliant on diamonds exports, it is not surprising that the positive growth in their prices boosts the real GDP and stock return. Although there was decline in export demand and diamond price during financial crisis, the impact was short lived as the country steadily recovered. The findings also indicate that exchange rate (ER) is negatively related to stock price. This could be attributed to the consecutive currency devaluation by 7.5 and 12 percent in 2004 and 2005, respectively. Furthermore, following a change in the exchange regime when the crawling band exchange rate mechanism was adopted at the time of the second devaluation in 2005, the real effective exchange rate experienced more fluctuations due to bilateral exchange rate volatility during the financial crisis. The results are similar to findings by Soenen and Hennigar (1988), Rahman et al. (2009) and Ibrahim and Aziz (2003). This implies that along a decrease in effective exchange rate or devaluation of domestic currency, there is a positive effect on profitability of export-oriented domestic firms ultimately leading to increase in stock prices. This indicates that currency devaluation can be beneficial to the stock market and is consistent with priori expectations and theory. The US government bond yield (USGBY) is negatively related to stock price. The negative result with the global interest rate is consistent with Hsing (2011). This negative relationship is also similar to how the stock price reacts to the domestic long term interest rate (RIR). Furthermore, the US share price index (USSPI) is significantly and negatively related with stock price, an indication that the US share price moves in the opposite direction with the domestic stock price. The results do not collaborate with the study by Hsing (2011) and Alshogeathri (2011). 
Table 5: Johansen normalized cointegrating results (long run)

\begin{tabular}{lllll}
\hline & Coef. & Std. Err. & $\mathbf{z}$ & $\mathbf{P}>\mathbf{Z}$ \\
\hline DCI & 1 & $\cdot$ & $\cdot$ & $\cdot$ \\
GDP & 4.85292 & 0.10222 & 47.47 & $0.000^{* * *}$ \\
RIR & -0.71503 & 0.00665 & -107.57 & $0.000^{* * *}$ \\
BoBCR & 0.61716 & 0.00644 & 95.82 & $0.000^{* * *}$ \\
M2 & -2.02903 & 0.02511 & -80.80 & $0.000^{* * *}$ \\
FR & -0.33112 & 0.01261 & -26.26 & $0.000^{* * *}$ \\
CPI & 0.54417 & 0.06855 & 7.94 & $0.000^{* * *}$ \\
DI & 0.45522 & 0.01555 & 29.27 & $0.000^{* * *}$ \\
ER & -1.33996 & 0.02518 & -53.21 & $0.000^{* * *}$ \\
USSPI & -3.20641 & 0.03688 & -86.95 & $0.000^{* * *}$ \\
USGBY & -0.96551 & 0.02467 & -39.14 & $0.000^{* * *}$ \\
Intercept & -18.87167 & 0.68743 & -27.45 & $0.000^{* * *}$ \\
\hline
\end{tabular}

*** significant at $1 \%,{ }^{* *}$ significant at $5 \%$ and ${ }^{*}$ significant at $10 \%$

Model Diagnostics: After estimating the results, some tests were carried out for the purpose of figuring out the adequacy of the model. First the Langrange-multiplier (LM) test for autocorrelation in the residuals is carried out. The results are reported in Table 6. High p-values indicate that we fail to reject the null hypothesis at 5\% significant level and conclude that there is no autocorrelation. Another test used is the Jarque-Bera test for normality (Table 6). Judging by the high p-value we fail to reject the null hypothesis of normality in the model at conventional $(\alpha=1 \%)$. Therefore, we conclude that the model is adequate.

Table 6: LM test for autocorrelation and Jarque-Bera test for normality

\begin{tabular}{lll}
\hline & chi2 & Prob $>$ chi2 \\
\hline LM Test for autocorrelation & 112.65 & 0.694 \\
Jarque-Bera test for normality & 0.277 & 0.877 \\
\hline
\end{tabular}

Checking for VECM stability: The VECM adequacy analysis is completed by checking if the eigenvalues stability conditions are satisfied. For a $K$-variable model with $r$ cointegrating relationships, the companion matrix will have $(K-r)$ unit eigenvalues. For stability, the moduli of the remaining $r$ eigenvalues should be strictly less than unity. As a benchmark, for instance in case of a two variable model with one lag $\Delta Y_{t}=\delta+\left(Z_{t}-1\right) Y_{t-1}+\varepsilon_{t}$, stability conditions imposed is that one eigenvalue of matrix $Z_{1}$ are such that one eigenvalue is equal to one and another is always smaller than one in absolute terms. As may be inferred from Figure 1, some of the eigenvalues are inside the unit circle and some equal to one, an indication that our model is stable.

\section{Conclusion}

This paper explored the relationship between the stock market price and selected macroeconomic variables in the Botswana stock market using quarterly data for the period 1998 to 2012. The main objective was to determine if there exist any long-run relationship between the selected macroeconomic variables and the stock market price, using Johansen's cointergration technique and VECM framework. The study showed that there exist a significant long-run relationship between the macroeconomic variables and the stock market price. The paper has highlighted how stock price relates with both domestic and global macroeconomic variables. Most results were consistent with economic theory and previous empirical findings. The results showed that in the long run, real GDP, short run interest rate, inflation and diamond index positively related with stock market price. However, real interest rate, money supply, foreign reserves, exchange rate, US share price index and US government bond yield negatively related with stock market price in the long run. The paper confirms that macroeconomic factors influence the Botswana stock market at varying levels. Contrary to the theory that emerging markets are not integrated with global markets, the study has shown that movements in global stock markets and interest rates have an effect in the Botswana stock market performance. Although the study did not address issues of efficiency, it is worth noting that the findings had to some extent highlighted the presence of association which may signal that the stock market is responsive to changes in real economic 
activities. Implications of the finding and evidence of cointegration will therefore be pivotal to policy makers and future research.

Figure 1: Eigenvalue stability test

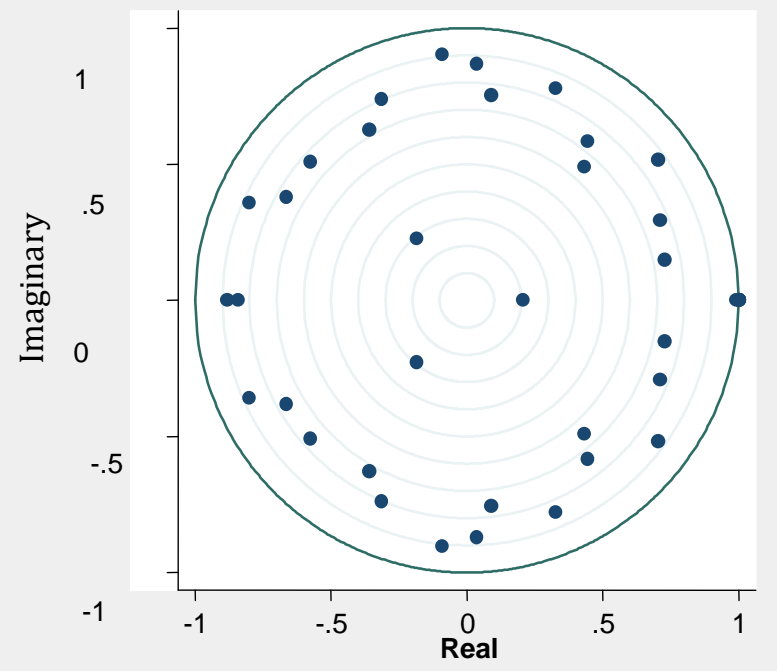

The VECM specification imposes 10 unit moduli

\section{References}

Abdullah, D. A. \& Hayworth, S. C. (1993). Macroeconometrics of Stock Price Fluctuations. Quarterly Journal of Business and Economics, 32(1), 50-67.

Adam, A. M. \& Frimpong, S. (2010). Can Stock Market Hedge Against Inflation in the Long Run? Evidence from Ghana Stock Market. International Journal of Business and Management, 5(6), 188-194.

Aggarwal, R. (1981). Exchange Rates and Stock Prices: A study of the US capital Markets Under Floating Exchange Rates. Akron Business and Economic Review, 12, 7-12.

Agrawalla, R. K. \& Tuteja, S. K. (2008). Share prices and macroeconomic variables in India: an approach to investigate the relationship between stock markets and economic growth. Journal of Management Research, 8(3), 136-146.

Ahmed, M. N. \& Imam, M. O. (2007). Macroeconomic Factors and Bangladesh Stock Market. International Review of Business Research Paper, 3(5), 21-35.

Aitt-Sahalia, Y., Parker J. A. \& Yogo, M. (2004). Luxury goods and the equity premium. Journal of Finance, 59(6), 2959-3004.

Al-Khazali, O. M. \& Pyun, C. S. (2004). Stock Prices and Inflation: New Evidence from the Pacific-Basin Countries. Review of Quantitative Finance and Accounting, 22(2), 123-140.

Alshogeathri, M. (2011). Macroeconomic Determinant of the Stock Market Movement: Empirical Evidence from the Saudi Stock Market. Kansas City University

Auer, B. R. \& Schuhmacher, F. (2013). Diamonds - A precious New Asset? International Review of Financial Analysis , 28, 182-189.

Baumol, W. J. (1965). The Stock Market and Economic Eficiency. New York: Fordham Univ. Press.

Black, F., Jensen, M. \& Scholes, M. (1972). The Capital Asset Pricing Model: Some Empirical Tests, in Studies in the Theory of Capital Markets. M. C. Jensen, ed. New York, Praeger. pp 79-121.

Bosworth, B. (1975). The Stock Market and the Economy. Brookings Papers on Economic Activity, 75(2), 257-300.

Chaudhuri, K. \& Smiles, S. (2004). Stock Market and Aggregate Economic Activity: Evidence from Australia. Applied Financial Economics, 14(9), 121-12.

Chen, N., Roll, R. \& Ross, S. A. (1986). Economic Forces and the Stock Market. Journal of Business, 59(3), 383-403.

Davis, N. \& Kutan, A. M. (2003). Inflation and Output as Predictors of Stock Returns and Volatility: International Evidence. Applied Financial Economics, 13(9), 693-700.

DeFina, R. H. (1991). Does Inflation Depress the Stock Market? Business Review, Federal Reserve Bank of Philadelphia, 3, 3-12. 
Dhakal, D., Kandil, M. \& Sharma, S. C. (1993). Causality Between the Money Supply and Share Prices: A VAR Investigation. Quarterly Journal of Business and Economics, 32(3), 52-74.

Dickey, D. A. \& Fuller, W. A. (1981). Likelihood Ratio Statistics for Autoregressive Time Series with a Unit Root. Econometrica, 49(4), 1057-72.

Dickey, D. A. \& Fuller, W. A. (1979). Distribution of the Estimators for Autoregressive Time Series with a Unit Root . Journal of the American Statistical Association, 74(366), 427-431.

Engle, R. F. \& Granger, C. W. (1987). Cointegration and Error Correction: Representation, Estimation and Testing. Econometrica, 55(2), 251-276.

Errunza, V. R. \& Hogan, K. (1998). Macroeconomic Determinants of European Stock Market Volatility. European Financial Management, 4(3), 361-377.

Fama, E. F. (1965). The Behaviour of Stock Market Prices. Journal of Business, 38(1), 35-105.

Fama, E. F. (1981). Stock Returns, Real Activity, Inflation and Money. The American Economic Review, 71(4), 545-565.

Fama, E. F. (1990). Stock Returns, Expected Returns, and Real Activity. Journal of Finance, American Finance Association, 45(4), 1089-1108.

Fama, E. F. \& French, K. R. (1989). Business Conditions and Expected Returns on Stocks and Bonds. Journal of Financial Economics, 25(1), 23-49.

Fama, E. F. \& Schwert, W. (1977). Asset Returns and Inflation. Journal of Financial Economics, 5, 115-146.

Fifield, S. G. M., Power, D. M. \& Sinclair, C (2002). Macroeconomic Factors and Share Returns: An Analysis Using Emerging Market Data. International Journal of Finance and Economics, 7(1), 51-62.

Fisher, I. (1930). The Theory of Interest. Macmillan, New York.

Floros, C. (2004). Stock Returns and Inflation in Greece. Applied Econometrics and International Development, 4, 12-25.

Friedman, M. (1988). Money and the Stock Market. Journal of Political Economy, 96(2), 221-245.

Galebotswe, 0. \& Tlhalefang, J. B. (2012). Monetary Policy Shocks and Stock Returns Reactions: Evidence from Botswana. Botswana Journal of Economics, 10(14), 79-108.

Geske, R. \& Roll, R. (1983). The Fiscal and Monetary Linkage between Stock Returns and Inflation. The Journal of Finance, 38(1), 1540-6261.

Gjerde, O. \& Saettem, F. (1999). Causal Relations Among Stock Returns and Macroeconomic Variables in a Small, Open Economy. Journal of International Financial Markets, Institutions and Money, 9(1), 6174.

Glen, J. (2002). Devaluations and Emerging Stock Market Returns. Emerging Markets Review , 3(4), 409428.

Granger, C. (1986). Developments in the Study of Cointegration Economic Variables. Oxford Bulletin of Economics and Statistics, 48(3), $213-228$.

Granger, C. W., Huang, B. \& Yang, C. (2000). A Bivariate Causality between Stock Prices and Exchange Rates: Evidence from Recent Asian Flu. The Quarterly Review of Economics and Finance, 40(3), $337-354$.

Hsing, Y. (2011). The Stock Market and Macroeconomic Variables in a BRICS Country and Policy Implications. International Journal of Economics and Financial Issues, 1(1), 12-18.

Humpe, A. \& Macmillan, P. (2009). Can Macroeconomic Variables Explain Long-term Stock Market Movements? A Comparison of the US and Japan. Applied Financial Economics, 19(2), 111-119.

Hussin, M., Muhammad, F., Salwa, A., Marwan, F. \& Azila, R. (2012). The Dynamic Interaction between Islamic Stock Market and Strategic Commodities. Journal of Islamic Economics, Banking and Finance, 9(3).

Ibrahim, M. (2000). Cointegration and Granger Causality Tests of Stock Price and Exchange Rate Interactions in Malaysia. ASEAN Economic Bulletin, 17(1), 36-47.

Ibrahim, M. (2003). Macroeconomic Forces and Capital Market Integration: A VAR Analysis for Malaysia. Journal of the Asia Pacific Economy, 8(1), 19-40.

Ibrahim, M. \& Aziz, L. (2003). Macroeconomic Variables and the Malaysian Equity Market. Journal of Economic Studies, 30(1), 6-27.

Ibrahim, M. \& Yusoff, M. (2001). Macroeconomics Variables and Stock Price in Malaysia: An Empirical Analysis. Asian Economic Journal, 13(2), 219-231.

Jefferis, K. \& Okeahalam, C. (2000). An Event Study of the Botswana, Zimbabwe and Johannesburg Stock Exchanges. South African Journal of Business Management, 30(4), 131-140.

Johansen, S. (1991). Estimation and Hypothesis Testing of Cointegration Vectors in Gaussian Vector Autoregressive Models. Econometrica, 59(6), 1555-1580.

Johansen, S. (1995). Likelihood Based Inferences in Cointegrated Vector Autoregressive Models. Oxford: Oxford University Press. 
Kumari, J. (2011). Stock Returns and Inflation in India: An Empirical Analysis. Department of Economics, University of Hyderabad, India, 36(6), 427-431.

Levenstein, M. \& Suslow, V. (2006). What Determines Cartel Success? Journal of Economic Literature, 44(1), 43-95.

Levine, R. \& Zervos, S. (1998). Stock Markets, Banks, and Economic Growth. American Economic Review, American Economic Association, 88(3), 537-58.

Maysami, R. C. \& Koh, T. S. (2000). A Vector Error Correction Model for the Singapore Stock Market. International Review of Economics and Finance, 9(1), 79-96.

Mitra, R. (2013). Foreign Aid and Economic Growth: A Cointegration Test for Cambodia. Journal of Economics and Behavioral Sciences, 5(2), 117-121.

Mookerjee, R. \& Yu, Q. (1997). Macroeconomic Variables and Stock Prices in a Small Open Economy: The Case of Singapore. Pacific Basin Finance Journal, 5(3), 377-388.

Muhammad, S. D., Hussain, A. \& Ali, A. (2009). Stock Prices: Empirical Evidence in Case of KSE (Karachi Stock Exchange). European Journal of Scientific Research, 38(1), 96-103.

Mukherjee, T. K. \& Naka, A. (1995). DynamicRelations Between Macroeconomic Variables and the Japanese Stock Market: An Application of a Vector Error Correction Model. The Journal of Financial Research, 18(2), 223-237.

Nasseh, A. \& Strauss, J. (2000). Stock Prices and Domestic and International Macroeconomic Activity: A Cointegration Approach. Quarterly Review of Economics and Finance, 40(2), 229-245.

Nemaorani, T. (2012). Impact of Monetary Policy on Stock Prices: Evidence from Botswana. Unpublished BA Economics Project, University of Botswana.

Omrana, M. (2003). Time Series Analysis of the Impact of Real Interest Rates on Stock Market Activity and Liquidity in Egypt: Co-integration and Error Correction Model Approach. International Journal of Business, 8(3), 358-374.

Phillips, P. C. \& Perron, P. (1988). Testing for a Unit Root in Time Series Regression: Possibly Integrated Processes. Journal of Econometrics, 66(1), 225-250.

Rahman, A. A., Noor, Z. M. \& Tafri, F. H. (2009). Macroeconimic Determinants of Malaysian Stock Market. African Journal of Business Management, 3(3), 95-106.

Ralph, U. I. \& Eriki, O. P. (2001). Inflation and Stock Price Behavior: Evidence from Nigerian Stock market. Journal of Financial Management \& Analysis, 14(1), 1-10.

Ratanapakorn, 0. \& Sharma, S. C. (2007). Dynamic Analysis Between the US Stock Returns and the Macroeconomic Variables. Applied Financial Economics, 17(5), 369-37.

Renneboog, L. \& Spaenjers, C. (2012). Hard Assets: The Returns on Rare Diamonds and Gems. Finance Research Letters, 9(4), 220-230.

Ritter, R. J. (2005). Economic Growth and Equity Returns. Pacific-Basin Finance Journal, 13(5), 489-503.

Ross, S. (1976). The Arbitrage Theory of Capital Asset Pricing. Journal of Economic Theory, 13(3), 341360.

Sharpe, W. F. (1964). Capital Asset Prices: A Theory of Market Equilibrium under Conditions of Risk. Journal of Finance, 19(3), 425-42.

Shevelyova, I. (2006). The World Diamond Market: Logic of the Organization and Functioning. Economics and Management, 2, 79-85.

Soenen, L. A. \& Hennigar, E. S. (1988). An Analysis of Exchange Rates and Stock prices: The US experience between 1980 and 1986. Akron Business and Economic Review, 19(4), 7-16.

Sohail, N. \& Hussain, Z. (2009). Long-run and Short-run Relationship between Macroeconomic Variables and Stock Prices in Pakistan: The Case of Lahore Stock Exchange. Pakistan Economic and Social Review, 47(2), 183-198.

Spar, D. (2006). Continuity and Change in the International Diamond Market. Journal of Economic Perspectives, 20(3), 195-208.

Spyrou, S. I. (2001). Stock Returns and Inflation: Evidence from an Emerging Market. Econometrics Reviews, 15(4), 369-386.

Spyrou, S. I. (2004). Are stocks a good hedge against inflation? Evidence from Emerging Markets. Applied Economics, Taylor and Francis Journals, 36(1), 41-48.

Srinivasan, P. (2011). Causal Nexus between Stock Market Return and Selected Macroeconomic Variables in India: Evidence from the National Stock Exchange (NSE). The IUP Journal of Financial Risk Management, 8(4), 7-24.

Disclaimer: The views expressed in this paper are entirely those of the author(s) and do not necessarily reflect the official opinion of Bank of Botswana or BIDPA where the authors are employed. 